М. І. Швед, С. М. Геряк, С. Й. Липовецька, Р. М. Ляхович, Л. В. Левицька, О. Л. Сидоренко, Я. М. Кіцак, Л. П. Мартинюк, О. А. Прокопович, В. Т. Гурський ДВНЗ “Тернопільський державний медичний університет імені I. Я. Горбачевського МОЗ України"

\title{
ОСНОВНІ НАПРЯМКИ ПІДГОТОВКИ ІНОЗЕМНИХ СТУДЕНТІВ НА КАФЕДРІ НЕВІДКЛАДНОЇ ТА ЕКСТРЕНОЇ МЕДИЧНОЇ ДОПОМОГИ
}

\author{
M. I. Shved, S. M. Geryak, S. Y. Lypovetska, R. M. Lyahovich, L. V. Levytska,
} O. L. Sydorenko, Y. M. Kitsak, L. P. Martynyuk, O. A. Prokopovich, V. T. Gurskyi

I. Horbachevsky Ternopil State Medical University

\section{MAIN WAYS OF TRAINING OF FOREIGN STUDENTS AT THE DEPARTMENT OF URGENCY AND EMERGENCY MEDICAL CARE}

\begin{abstract}
Мета роботи - аналіз ефективності навчально-виховної роботи серед іноземних студентів на опорній кафедрі невідкладної та екстреної медичної допомоги щодо засвоєння ними клінічних знань та практичних навичок із невідкладної медицини, а також оцінка перспективи впровадження нових сучасних віртуальних навчально-контролюючих програм.

Основна частина. Апробовані на кафедрі невідкладної та екстреної медичної допомоги сучасні навчально-виховні методики роботи з іноземними студентами (єдиного навчального дня, проведення занять у навчальному симуляційно-тренінговому центрі, використання сучасних європейських віртуальних навчальних програм, групові та індивідуальні заняття з іноземними студентами з урахуванням їх етнічно-релігійних особливостей) $є$ досить перспективними напрямками в педагогічному процесі. Так, використання в навчальному процесі на кафедрі системи єдиного навчального дня протягом 6 годин дає змогу не лише глибоко проаналізувати зі студентами теоретичні питання за темою заняття, але й впровадити в навчання елементи симуляційно-тренінгового засвоєння практичних навичок. Високий методичний рівень забезпечення навчального процесу на кафедрі, наявність університетського навчально-тренінгового центру симуляційного навчання за адаптованими європейськими віртуальними навчально-контролюючими програмами та широке залучення студентів-гуртківців у науковий, навчальний та тренінговий процес дозволяють забезпечити високий кінцевий рівень засвоєння ними теоретичних знань та практичних навичок.

Висновок. Навчання за системою єдиного навчального дня дає змогу враховувати етнокультурні та релігійні особливості іноземних студентів та впровадити елементи симуляційно-тренінгового засвоєння практичних навичок.
\end{abstract}

Ключові слова: навчальний процес; симуляційно-тренінгове навчання; віртуальні навчально-контролюючі програми.

The aim of the work - to analyze the effectiveness of educational work among foreign students at the department of emergency and urgency medical care in order to assimilate their clinical knowledge and practical skills in emergency medicine, as well as assess the prospects for the introduction of modern virtual teaching and control programs.

The main body. Approved modern teaching methods with foreign students at the department of urgency and emergency medical care in particular single academic day, conducting classes in a training simulation training center, using of modern European virtual training programs, group and individual classes with foreign students, taking into account their ethnically-religious peculiarities are quite promising directions in the pedagogical process. Method of single academic day gives an opportunity not only to analyze deeply theoretical questions, but also to introduce training elements of simulation and training acquisition of practical skills. The high methodological level of the educational process, availability of university teaching center for simulation training in adapted European virtual programs and wide involvement of students in the scientific, educational and training process provide a high final level of their theoretical knowledge and practical skills.

Conclusion. The system of single academic day enables to take into account the ethno-cultural and religious features of foreign students and introduce simulation-training acquisition of practical skills.

Key words: educational process; simulation-training education; virtual training and self-controlling programs.

Вступ. Прагнення молоді зарубіжних країн опанувати медицину та здобути фах лікаря у вищих навчальних закладах України є реаліями сьогодення. Чільне місце у підготовці кваліфікованих спеціа-

( ) М. І. Швед, С. М. Геряк, С. Й. Липовецька та ін. лістів займає ТДМУ ім. І. Я. Горбачевського. За результатами здачі кваліфікаційних іспитів “Крок 2" i “Крок 3”, протягом останніх 5 років університет впевнено лідирує в Україні, посідаючи 1-3 місце в державному рейтингу. 
Незважаючи на певні труднощі, які виникають у процесі навчання, а саме дещо відмінні етнокультурні цінності різних національностей [6], певні релігійні переконання та світогляд, недосконале знання української та/або російської мов, завищену самооцінку знань та вмінь, яку мають чимало іноземних студентів, небажання дотримуватися дисципліни, на кафедрі невідкладної та екстреної медичної допомоги створено належні умови для засвоєння основ інтерністики та підготовки майбутніх спеціалістів, які б успішно надавали медичну допомогу населенню своїх країн.

Мета роботи - аналіз ефективності навчальновиховної роботи студентів на опорній кафедрі невідкладної та екстреної медичної допомоги щодо засвоєння ними клінічних знань та практичних навичок з невідкладної медицини, а також оцінка перспективи впровадження нових сучасних віртуальних навчально-контролюючих програм для студентів та інтерністів.

Основна частина. Особливо важливою ланкою в навчальному процесі співробітники кафедри вважають створення сучасної навчально-методичної бази, тому вже з перших днів роботи новоствореної кафедри була підготовлена відповідна методична документація і видано типографським способом посібник з екстреної та невідкладної допомоги (2013). У 2015 р. вийшов у світ навчальний посібник “Екстрена медична допомога”, створений співробітниками кафедри. У ньому висвітлено основи організації і надання екстреної медичної допомоги бригадами Е(Ш)МД при їх повсякденній діяльності та у випадках надзвичайних ситуацій із застосуванням сучасних клінічних протоколів. Видання відповідає типовій навчальній програмі з екстреної і невідкладної медичної допомоги, затвердженій Центральним методичним кабінетом 3 вищої медичної освіти МОЗ України, який у 2016 р. рекомендував даний посібник як національний підручник. У 2017 та 2018 роках співробітники кафедри підготували і видали два посібники “Екстрена та невідкладна медична допомога в запитаннях і відповідях" українською та англійською мовами.

На кафедрі невідкладної і екстреної медичної допомоги навчаються студенти 4, 5 і 6 курсів іноземного медичного та стоматологічного факультетів. Вони поетапно освоюють чотири модулі [1, 2] 3 внутрішньої медицини, які розроблені відповідно до типової програми. Особливо важливим фактором підвищення практичної підготовки студентів, якісної оцінки практичних навичок і постійного динамічного контролю за засвоєнням практичних на- вичок з елементами зворотного зв'язку стало створення в 2015 р. при університеті симуляційного тренінгового центру та придбання для його оснащення не лише відповідних манекенів та маніпуляторів, а й віртуальних навчально-методичних програм (Body Interact) з методики своєчасної діагностики та надання адекватної невідкладної медичної допомоги при різноманітних клінічних ситуаціях [9]. Важливо підкреслити, що в основі вищевказаних віртуальних навчально-самоконтролюючих програм покладено вимоги сучасних європейських протоколів та рекомендацій відповідних європейських асоціацій.

Варто також зупинитися на більш детальному описі функціональних можливостей, наявних у симуляційному центрі, симулятора-манекена норвезької фірми Laerdal, який використовується при цьому. Манекен дає можливість відпрацювання ряду маніпуляцій та навиків, що знадобляться в лікарській практиці завдяки широким можливостям симуляції функцій життєдіяльності в нормі та при патології. Для тренування проведення серцеволегеневої та мозкової реанімації передбачено можливість штучної вентиляції легень способами рот до рота, рот до носа, масковим, через інтубаційну трубку, ларингеальну маску тощо; аналізується кількість, частота, об’єм дихань; фіксується кількість, частота, співвідношення з диханням і глибина компресій та положення рук реаніматора при проведенні непрямого масажу серця; графічне відображення виконання елементів серцево-легеневої реанімації з голосовими підказками англійською мовою. У випадку успішного оживлення зіниці манекена змінять розміри від розширених до нормальних, з’явиться артеріальна пульсація та спонтанне дихання [2, 5].

Автоматичний зовнішній дефібрилятор, що входить до комплекту симулятора, є навчальним і не придатний для проведення електроімпульсної терапії хворим, проте успішно застосовується з тренувальною метою, достовірно імітуючи функції справжнього автоматичного зовнішнього дефібрилятора. У віртуальному режимі, завдяки мультимедійній анімації, на екрані комп’ютера відпрацьовуються навики роботи зі звичайним дефібрилятором та водієм ритму. Багатофункціональний монітор стану пацієнта-манекена також є навчальним і відображає ЕКГ у 12 відведеннях (з найрізноманітнішими варіантами порушень серцевого ритму чи коронарного кровообігу), криву дихальних рухів, сатурацію крові киснем, вміст вуглекислого газу у видихуваному повітрі, артеріальний тиск. Передба- 
чено різні варіанти аускультативної картини серця та легень при патології та в нормі $[4,6]$.

Описаний тренажер є комплексною системою для відпрацювання навичок з надання невідкладної допомоги і включає в себе власне манекен, навчальний багатофункціональний монітор стану пацієнта, навчальний автоматичний зовнішній дефібрилятор, модуль медикаментозної терапії з понад 30 препаратами. Взаємодія вказаних складових між собою та з користувачем відбувається через персональний комп’ютер. Комп’ютерне програмне забезпечення, що додається виробником, було створене відповідно до настанов Американської асоціації серцевих захворювань 2012 року з серцево-легеневої реанімації та невідкладної допомоги при серцевосудинних захворюваннях, проте піддається корекції відповідно до навчальних потреб, зокрема завдяки можливості створення та редагування сценаріїв. Даний комплекс дає змогу студентам здобувати та вдосконалювати практичні навички з екстреної допомоги, закріплюючи тим самим теоретичні знання, які обов’ язково необхідні для правильного виконання передбачених сценаріями завдань. Також у симуляційному центрі використовуються манекени-тренажери для відпрацювання практичних навичок з проведення декомпресії грудної клітки при напруженому пневмо(гемо)тораксі, постановці ларингеальних масок, трубок, комбітьюба. Особлива увага приділяється освоєнню обладнання із забезпечення внутрішньокісткового доступу з використанням навчального бонін’ єктора, виконання конікопункції, конікотомії [6-9].

Загалом симуляційна підготовка студентів - це вид навчальних занять, де викладач формує вміння й навички практичного застосування набутих теоретичних знань шляхом індивідуального виконання студентом завдань, визначення загальної тактики, діагностики та лікування симульованих пацієнтів у змодельованій ситуації невідкладного стану, в тому числі й при масових ураженнях на основі існуючих стандартних схем. Завдання студента чи групи студентів полягає у виконанні в реальному часі стандартного алгоритму організаційних і діагностичних дій, визначення симптомів, їх аналізу й узагальнення, діагностиці наявного невідкладного стану та застосуванні відповідного протоколу, при якому на конкретній особі (симулянті) чи манекені за допомогою додаткових технічних засобів імітується певний невідкладний стан, який вимагає надання екстреної медичної допомоги. При цьому кожен студент навчальної групи індивідуально відпрацьовує сценарій того чи іншого невідкладного стану, передбаченого планом заняття. Робота проводиться студентом самостійно або у групі (лідер, учасник). Подібні навчання відбуваються у вигляді гри, де кожен із студентів виступає в якості того чи іншого працівника швидкої, відповідального за свій напрямок догоспітальної медичної допомоги $[7,10]$.

Важливо відмітити, що своєрідним якісним перехідним етапом у навчальному процесі студентів на кафедрі невідкладної та екстреної медичної допомоги стало впровадження в навчальний процес 11 симуляційних віртуальних європейських навчально-самоконтроюючих програм (Body Interact) 3 методики своєчасної діагностики та надання адекватної невідкладної медичної допомоги при різноманітних клінічних ситуаціях - гострому коронарному синдромі, ускладненому гіпертензивному кризі, порушеннях ритму та провідності, шоках різної етіології, тромбоемболічних ускладненнях, кровотечах тощо [13]. На освоєння кожної теми (відповідної клінічної ситуації) студенту надається 45-60 хвилин. Віртуальна програма створена так, що на моніторі з'являється пацієнт із симптомами відповідного невідкладного стану, студент може додатково отримати інформацію у вигляді результатів лабораторних тестів або інструментального дослідження (рентгенограми, ЕКГ, ЕхоКГ, УЗД, комп’ютерної томографії, ЯРМ, коронароангіографії тощо), що допомагає йому своєчасно діагностувати проблему та визначити послідовність надання невідкладної медичної допомоги. Зауважимо, що при встановленні студентом невірного діагнозу або несвоєчасному і неправильному наданні меддопомоги клінічний стан віртуального пацієнта прогресивно погіршується i, якщо студент не надасть адекватної допомоги, то потерпілий переходить у стан агонії і клінічної смерті, а студент повинен провести серцево-легеневу і мозкову реанімацію. Важливо підкреслити, що в основі вищевказаних віртуальних навчально-самоконтролюючих програм покладено вимоги і правила сучасних європейських протоколів та рекомендацій відповідних європейських асоціацій.

Впровадження методики “Єдиного дня”, циклової системи навчання дозволяє студентам брати безпосередню участь у роботі клініки, в діагностично-лікувальному процесі. Проте часто налагодженню вільного діалогу з пацієнтами на перепоні стають недостатні мовна практика і багаж знань, різні вікові категорії студента та пацієнта, а також часто змінений психоемоційний стан останнього на Ірунті хронічних соматичних [3]. На цьому етапі вкрай важливим є професіоналізм викладача, 
який повинен постійно і ненав’язливо, теоретично i на власному прикладі допомогти кожному студенту налагодити контакт із пацієнтами з метою найбільш глибокого і ефективного освоєння практичних, комунікативних навиків і набування професійних вмінь [5].

При обстеженні пацієнтів студенти повинні дотримуватися таких комунікативних алгоритмів: привітний вираз обличчя, усмішка; лагідний тон розмови; привітання та представлення, прояв інтересу, поваги та турботи; встановлення контакту з пацієнтом та намагання викликати його довіру; пояснення результатів обстеження; пояснення дій (госпіталізація, проведення певних обстежень), які плануються до виконання в майбутньому; залучення пацієнта до бесіди (акцент на важливості безперервного лікування, дотримання призначеної схеми лікування, з'ясування, чи зрозумілі для пацієнта ваші пояснення); завершення бесіди.

Слід зауважити, що прості, на перший погляд, речі: чистий халат, усмішка, вітання, шанобливе поводження - дозволяють налаштувати пацієнта на плідну співпрацю із студентом. Доречним $\epsilon$ на початку щоденної роботи з хворим проводити інструктаж студентів із акцентуванням уваги на нюансах роботи з окремим категоріями пацієнтів, особливостях обстеження при різних патологічних станах. У певних випадках, особливо на початку семестру, студентам 4 i 5 курсів бажано нагадувати основні пропедевтичні прийоми щодо скарг, анамнезу, об'єктивного обстеження хворих. Оскільки незнання чи невміння погіршують або, навіть, i перешкоджають роботі в клініці, біля ліжка хворого. Вважається доречним й проведення тематичних обходів, де доповідачем історії захворювання та інтерпретації додаткових методів обстеження є студент.

Введення циклової системи навчання дозволило угрупувати додаткові засоби до практичних занять, створити оснащені тематичні навчальні кімнати. Багаторічний досвід ведення циклів фахівцями свідчить про те, що саме такий підхід дає змогу підвищити якість оволодіння практичними навичками як біля ліжка хворого, так і за умов інтерпретації додаткових методів обстеження.

Одним із пунктів в опануванні теоретичного матеріалу є лекції. При читанні лекцій необхідно враховувати ряд особливостей підготовки фахівців у медичних ВНЗ: викладання матеріалу не може бути суто теоретичним, воно повинно мати у своїй основі практичне спрямування. При цьому необхідним $\epsilon$ як орієнтування на світові та українські стандарти діагностики та лікування захворювань внутрішніх органів, на результати світових багатоцентрових досліджень, так і на клінічний досвід провідних світових клінік вчених і власні спостереження лектора.

Мультимедійний супровід значно покращує сприйняття слухачами матеріалу, що подається, за рахунок не лише слухового, але і візуального сприйняття. Важливим моментом у підвищенні ефективності даного методу навчання було би спонукання не лише до пасивного, але і до активного їх прослуховування. Вважаємо, що з цією метою доцільно було б впровадити елемент інтерактивного спілкування зі студентами. Включення в лекцію коротких тестових завдань або невеликих ситуаційних задач із декількома відповідями спонукало би студентів не лише уважно слухати, але й аналізувати отриману інформацію, у тому числі готуватися до ліцензійного іспиту “Крок 2”. Звичайно, нераціонально обтяжувати лекцію багатьма запитаннями, оскільки це може не лише забирати багато часу, але і відволікати студентів від лектора і теми лекції. Проте неправильні відповіді змусили б слухачів бути уважнішими i, можливо, частіше переглядати розміщені на WEB-порталі університету презентації лекцій та матеріали підготовки до них чи, навіть, готуватися додатково до тієї чи іншої лекції. Цьому сприяє виділення “лекційного” дня в кожному навчальному тижні.

Самостійна, індивідуальна робота студентів $\epsilon$ чи не найбільш важливою складовою освіти. Написання рефератів із тем позааудиторної роботи студентами ми вважали доречним замінити на підготовку коротких мультимедійних презентацій. Необхідність представлення підготовленого матеріалу одногрупникам сприяє плідній роботі з підручниками, журналами, проведенню пошуку в Інтернеті, дозволяє глибше освоїти матеріал. Запитання студентів і відповіді доповідача сприяють розвитку клінічного мислення.

Здача тестових завдань Moodle [1, 4] чи написання вихідного тестового контролю на кожному практичному занятті й освоєння практичних навичок із записом у матрикулярних книжках $є$ вагомими методами рутинного щоденного контролю за засвоєнням теоретичного та набуванням практичного досвіду студентами. Проведення об'єктивного структурованого клінічного іспиту $[2,14,15]$ та кінцевого тесового контролю знань $є$ логічним етапом контролю у підготовці майбутніх спеціалістів.

Важливою складовою у досягненні кінцевої мети $€$ врахування релігійних вірувань як студента, так і хворого. При виконанні даного завдання перед нами постає декілька проблем. 3 одного боку, пацієнти 
України хоч і мають різні віросповідання, проте вони, як правило, християнського спрямування (католики і православні). 3 іншого боку, в ТДМУ навчаються не лише українці, але і понад 1500 студентів з близько 50 інших країн, яким не завжди близькі релігійні вподобання пацієнтів. Релігійна різноманітність у цьому контексті вимагає більшої толерантності до різних стилів життя і вірувань студентів. Тому важливим завданням педагогічного колективу медуніверситету $є$ не лише допомога в оволодінні практичними навичками і професійними вміннями, але і в налагодженні контактів із пацієнтами завдяки комунікативній майстерності, навчання терпимості до інших світоглядів та різних релігійних віросповідань.

На допомогу у вирішенні даних питань приходить проведення циклів релігієзнавства. Для студентів обладнані в гуртожитках кімнати для молитов і здійснення релігійних обрядів, відповідно до вірувань студентів.

3 метою оптимізації навчального процесу іноземних студентів доречним є розумне поєднання впливу на національну гордість, патріотизм та вимогливості в оволодінні теоретичними знаннями та практичними навиками.

Ще одним важливим елементом наукової та практичної діяльності кафедри невідкладної та екстреної допомоги є організація і проведення щорічних обласних змагань бригад Е(Ш)МД Тернопілля, на яких викладачі виступають в якості суддів, а студенти-гуртківці - позурантів. По завершенні змагань співробітники кафедри проводять аналіз виступів бригад на кожному конкурсі у вигляді науковопрактичної конференції, кінцевою метою якої є підвищення теоретичної підготовки та практичних навичок працівників швидкої медичної допомоги.

Загалом, можна зробити висновок, що апробовані нами сучасні навчально-виховні методики роботи 3 іноземними студентами є досить перспективними напрямками в педагогічному процесі. Так, використання в навчальному процесі на кафедрі невідкладної та екстреної медичної допомоги системи єдиного навчального дня протягом 6 годин дає змогу не лише глибоко проаналізувати зі студентами теоретичні питання за темою заняття, але й впровадити в навчання елементи симуляційно-тренінгового засвоєння практичних навичок. Високий методичний рівень забезпечення навчального процесу на кафедрі, наявність університетського навчально-тренінгового центру симуляційного навчання за адаптованими європейськими віртуальними навчально-контролюючими програмами й широке залучення студентів-гуртківців у науковий, навчальний та тренінговий процес дозволяє забезпечити високий кінцевий рівень засвоєння ними теоретичних знань та практичних навичок.

Висновки. 1. Навчально-виховний процес на кафедрі невідкладної та екстреної медичної допомоги за системою єдиного навчального дня дає змогу враховувати етнокультурні та релігійні особливості іноземних студентів і впровадити в навчання елементи симуляційно-тренінгового засвоєння практичних навичок.

2. Виїзди студентів на виклики в складі бригад швидкої (екстреної) медичної допомоги суттєво мотивують професійну орієнтацію та підвищують рівень засвоєння дисципліни.

3. Високий методичний рівень забезпечення навчального процесу на кафедрі, наявність університетського навчально-тренінгового центру симуляційного навчання за адаптованими європейськими віртуальними навчально-контролюючими програмами дозволяє забезпечити високий кінцевий рівень засвоєння іноземними студентами теоретичних знань та практичних навичок.

4. Медицина неотложных состояний. Избранные клинические лекции. Т. 1 / под ред. В. В. Никонова, А. Э. Феськова. - Д., 2008. - 503 с.

5. Болонський процес і система організації практичної підготовки студентів / Є. М. Нейко, Л. В. Глушко, М. І. Мізюк, І. П. Вакалюк // Медична освіта. - 2007. № 2. - С. 56-58.

6. Рощін Г. Г. Екстрена медична допомога: догоспітальний етап - алгоритми маніпуляції (базовий рівень) / Г. Г. Рощін, А. А. Гудима, В. Ю. Кузьмін. - К., 2012. - 84 с. 7. Рощін Г. Г. Методичні рекомендації для завідувачів кафедр невідкладної та екстреної медичної допомоги / 
Г. Г. Рощін, В. О. Крілюк. - К. : Медицина, 2014. С. 3-18.

8. Соков Л. П. Курс медицины катастроф : учебник / Л. П. Соков, С. Л. Соков. - М. : Изд-во РУДН, 2015. - 328 с.

9. Медицина надзвичайних ситуацій. Організація надання першої медичної допомоги : підручник / [В. С. Тарасюк, М. В. Матвійчук, І. В. Паламар та ін.]. - К. : Медицина, 2011. - 526 с.

10. Екстрена та невідкладна медична допомога / [M. I. Швед, А. А. Гудима, С. М. Геряк та ін.]. - 2-ге вид. - Тернопіль : ТДМУ, 2016. - С. 47-59.

11. Симуляційно-тренінгова підготовка студентів на кафедрі невідкладної та екстреної медичної допомоги важлива складова у навчальному процесі / М. І. Швед, Р. М. Ляхович, Л. П. Мартинюк, Я. М. Кіцак // Інноваційні технології в науці та освіті, європейський досвід : матеріали Міжнар. конф. - Відень, 2017. - Т. 1. - С. 177-183.

\section{References}

1. Kovalchuk, L.Ya. (2011). Rezultaty realizatsii kontseptsii rozvytku Ternopilskoho derzhavnoho medychnoho universitetu im. I. Ya. Horbachevskoho na shliakhu yoho vhodzhennia u svitovyi osvitnii prostir [Results of realization of development concept of I. Horbachevsky Ternopil State Medical University on its way to world educational space]. Medychna osvita Medical Education, 2, 12-20 [in Ukrainian].

2. Koshelev, A.A. (2015). Medycyna katastrof. Teoriia i praktyka [Medecine of catastrophe. Theory and practice]. Saint-Petersburg: ELBI-SPb [in Russian].

3. Zozulia, I.S. (Ed.) (2012). Medytsyna nevidkladnykh staniv: shvydka i nevidkladna medychna dopomoha [Emergency medicine: emergency medical care]. Kyiv: VSV Medytsyna [in Ukrainian].

4. Nikonov, V.V. (Ed.). (2008). Meditsina neotlozhnykh sostoyaniy. Izbraniye klinicheskiye lektsii [Emergency medicine. Selected clinical lectures]. [in Russian].

5. Neiko, Ye.M., Hlushko, L.V., Miziuk, M.I., \& Vakaliuk, I.P. (2007). Bolonskyi protsess i systema orhanizatsii praktychnoi pidhotovky studentiv [Bologna process and system of organization of students' practical preparation]. Medychna osvita - Medical Education, 2, 56-58 [in Ukrainian].

6. Roshchin, H.H., Hudyma, A.A., \& Kuzmin, V.Yu. (2012). Ekstrena medychna dopomoha: dohospitalnyi etap - alhorytm manipuliatsii (bazovyi riven) [Emergency medicine: prehospital stage-algorithm of manipulation (basic level)]. Kyiv [in Ukrainian].

7. Roshchin, H.H., \& Kryliuk, V.O. (2014). Metodychni rekomendatsii dlia zaviduvachiv kafedr nevidlkadnoi ta ekstrenoi medychnoi dopomohy [Methodical instructions or leaders of departments of emergency and urgency medical care]. Kyiv: Medytsyna [in Ukrainian].

8. Sokov, L.P., \& Sokov, S.L. (2015). Kurs meditsiny katasrof: Uchebnik [Course of medicine of catastrophe. Textbook]. Moscow: RUDN [in Russian].
12. Can medical students from two cultures learn effectively from a shared web-based learning environment? / P. Evans, Y. Suzuki, M. Begg, W. Lam // Medical Education. - 2008. - Vol. 42. - P. 27-33.

13. The wave of the future in clinical education. Body interact Clinical Education. [Internet]. Retrieved from : https://bodyinteract.com.

14. Roberts J. H. Students perception of race, ethnicity and culture at two UK medical schools: a qualitative study / J. H. Roberts, T. Sanders, V. Wass // Medical Education. 2008. - Vol. 42. - P. 45-52.

15. A consensus-based educational framework and competency set for the discipline of disaster medicine and public health preparedness / I. Subbarao, J. Lyznicki, E. Hsu [et al.] // Disaster Med Public Health Preparedness. - 2008. No. 2. - P. 57-68.

9. Tarasiuk, V.S., Matviichuk, M.V., Palamar, I.V., Koroliva, N.D., Kuchanska, H.B., \& Novitskyi, N.O. (2011). Medytsyna nadzvychainykh sytuatsii. Orhanizatsiia nadannia pershoi medychnoi dopomohy. Pidrichnyk [Emergency medicine. Textbook]. Kyiv: Medytsyna [in Ukrainian].

10. Shved, M.I., Hudyma, A.A., \& Heriak, S.M. (2016). Ekstrena ta nevidkladna medychna dopomoha (2he vyd.) [Emergency and urgency medicine (2nd ed.) edition]. Ternopil: TDMU Ukrmedknyha [in Ukrainian].

11. Shved, M.I., Liahovych, R.M., Martyniuk, L.P., \& Kitsak, Ya.M. (2017). Symuliatsiino-treninhova pidhotovka studentiv na kafedri nevidkladnoi ta ekstrenoi medychnoi dopomohy - vazhlyva skladova u navchalnomu protsesi [Simulation and training preparation of students at the department of emergency and urgency medical care - important part in teaching precess]. Proceedings of the International Scientific and Practical Conference "Innovative technologies in science and education, European experience, 1, (pp. 177-183). Wien [in Ukrainian].

12. Evans, P., Suzuki, Y., Begg, M., \& Lam, W. (2008). Can medical students from two cultures learn effectively from a shared web-based learning environment? Medical Education, 42, 27-33.

13. The wave of the future in clinical education. Body Interakt Clinical Education. [Internet]. Retrieved from : https://bodyinteract.com.

14. Roberts, J.H., Sanders, T., \& Wass, V. (2008). Students' perception of race, ethnicity and culture at two UK medical schools: a qualitative study. Medical Education, 42, 45-52.

15. Subbarao, I., Lyznicki, J., Hsu, E., Gebbie, K.M., Markenson, D., Barzansky, B., ... James, J.J. (2008). A consensusbased educational framework and competency set for the discipline of disaster medicine and public health preparedness. Disaster Med. Public Health Preparedness, 2, 57-68. 